\title{
Characteristics and assessment of
} biogenic phosphorus in sediments from the multi-polluted Haihe River, China, using phosphorus fractionation and phosphorus-31 nuclear magnetic resonance ( $\left.{ }^{31} \mathrm{P}-\mathrm{NMR}\right)$

W. Q. Zhang ${ }^{1,2}$, H. Zhang ${ }^{1}$, W. Z. Tang ${ }^{1}$, and B. Q. Shan ${ }^{1}$

${ }^{1}$ State Key Laboratory on Environmental Aquatic Chemistry, Research Center for Eco-Environmental Science, Chinese Academy of Science, Beijing 100085, China ${ }^{2}$ University of Chinese Academy of Science, Beijing 100049, China

Received: 12 September 2013 - Accepted: 8 October 2013 - Published: 22 October 2013 Correspondence to: B. Q. Shan (bqshan@ @rcees.ac.cn)

Published by Copernicus Publications on behalf of the European Geosciences Union.

\section{Biogenic-P in}

multi-polluted river sediment

W. Q. Zhang et al.

Title Page

Abstract Introduction

Conclusions

Tables References Figures

14 $\rightarrow$

4

Back

Close

Printer-friendly Version

Interactive Discussion 


\section{Abstract}

We studied the phosphorus $(\mathrm{P})$ pollution, as described by concentrations, distribution and transformation potential, of sediments of the water scarce and heavily polluted Fuyang River, a tributary of the Haihe River, using $P$ fractionation and phosphorus-31

5 nuclear magnetic resonance ( $\left.{ }^{31} \mathrm{P}-\mathrm{NMR}\right)$. The sediments of the Fuyang River accumulate significant amounts of inorganic phosphorus $(\mathrm{Pi})$ and organic phosphorus (Po) from industrial and domestic wastewater and agricultural non-point pollution. In terms of their contribution to total phosphorus, the rank order of the $\mathrm{P}$ fractions was as follows: $\mathrm{H}_{2} \mathrm{SO}_{4}-\mathrm{P}>\mathrm{NaOH}-\mathrm{Pi}>\mathrm{Res}-\mathrm{P}>\mathrm{NaOH}-\mathrm{Po}>\mathrm{KCl}-\mathrm{P}$ and their average relative proportions were $69.7: 47.5: 15.9: 2.9: 1.0$ (the proportion was based on the average proportion of the $\mathrm{KCl}-\mathrm{P}$ ). Seven $\mathrm{P}$ compounds were detected by the ${ }^{31} \mathrm{P}-\mathrm{NMR}$ analysis. Orthophosphate (Ortho-P: 45.2-92.4\%) and orthophosphate monoesters (monoP: $6.6-45.7 \%$ ) were the dominant forms. Smaller amounts of pyrophosphates (pyroP: 0.1-6.6\%), deoxyribonucleic acid (DNA-P: 0.3-3.9\%), phosphonates (phon-P: 0$3.3 \%$ ), phospholipids (lipids-P: 0-2.7\%) and polyphosphate (poly-P: 0-0.04\%) were observed in the sediments. Results of $\mathrm{P}$ fractionation and ${ }^{31} \mathrm{P}-\mathrm{NMR}$ analysis showed that $35 \%$ of $\mathrm{Pi}$ was labile $\mathrm{P}$, including $\mathrm{KCl}-\mathrm{P}$ and $\mathrm{NaOH}-\mathrm{Pi}$ (Fe-P and Al-P). Biogenic$P$ accounted for $24 \%$ of $P$ in the sediments. Analysis of the relationships between $P$ species and water quality indicated that the Po compounds would mineralize to form ortho-P and would be potentially bioavailable for recycling to surface water, supporting further growth of phytoplankton and leading to algal blooms.

\section{Introduction}

Phosphorus $(P)$ is a limiting element in freshwater systems. Excessive imports of $P$ cause eutrophication (Ahlgren et al., 2005). Eutrophication of freshwater systems has become one of the most severe environmental problems in developing countries (Pernet-Coudrier et al., 2012). The issue is particularly serious in northern China,
BGD

10, 16269-16294, 2013

\section{Biogenic-P in \\ multi-polluted river sediment \\ W. Q. Zhang et al.}

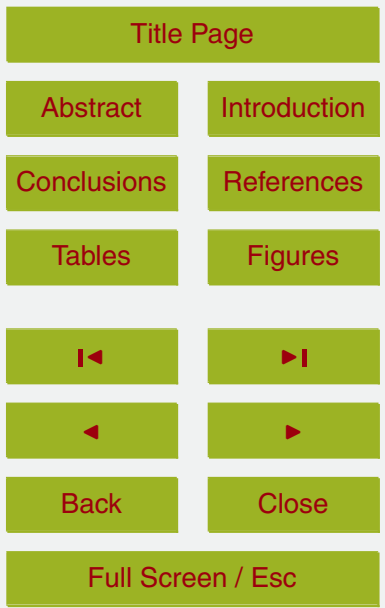

Printer-friendly Version

Interactive Discussion 
which is experiencing increasingly severe water shortages due to the rapid growth in population, industry and agriculture. The consequences of eutrophication include algal blooms, oxygen depletion, fish kills, aquatic ecosystem deterioration and increasing water treatment costs to ensure freshwater is suitable for human use (Vörösmarty 5 et al., 2010; Nyenje et al., 2010).

The release of $P$ from sediment is an important nutrient source that will induce continuous eutrophication in freshwater systems even if external inputs are reduced (Ramm and Scheps, 1997; Viktorsson et al., 2013). Sediment P includes inorganic P (Pi) and organic $\mathrm{P}(\mathrm{Po})$. The mineralization of $\mathrm{Po}$ into $\mathrm{Pi}$ has a direct effect on $\mathrm{P}$ bioavailability 10 in freshwater systems (Wang and Pant, 2010). However, until now, investigations of the species, concentrations, dynamics and effects of Po in sediment have been limited because of its complexity and limitations of analytical methods (Cade-Menun, 2005; Turner et al., 2005).

Phosphorus-31 nuclear magnetic resonance spectroscopy $\left({ }^{31} \mathrm{P}-\mathrm{NMR}\right)$ is a non15 destructive, non-invasive technique for identifying chemical forms that has the advantage of enabling multiple $P$ compounds to be characterized simultaneously with distinct binding properties (Cade-Menun, 2005). Since the first application of ${ }^{31} \mathrm{P}-\mathrm{NMR}$ in soil $P$ analysis (Turner et al., 2005), several $P$ compounds have been detected by ${ }^{31} \mathrm{P}-\mathrm{NMR}$, including phosphonates (phon-P), orthophosphate (ortho-P), orthophosphate monoesters (mono-P), orthophosphate diesters (diester-P: lipid-P and DNA-P), pyrophosphate (pyro-P) and polyphosphate (poly-P) (Newman and Tate, 1980). Therefore, it is an ideal technique to use to analyse Po species in marine or freshwater sediments, as it will not only provide useful information pertaining to $\mathrm{P}$ biogeochemical cycling in aquatic environments, but will also yield sufficient insight into the identifica25 tion of specific $\mathrm{P}$ compounds. The ${ }^{31} \mathrm{P}-\mathrm{NMR}$ method has been used to analyze Po on its own, Po compounds (Cade-Menun et al., 2005; Bai et al., 2009), Po transformations and their potential effects (Ahlgren et al., 2005; Reitzel et al., 2007), aluminum dosing effects on eutrophication management (Reitzel et al., 2006, 2009) and P biogeochemistry (Shinohara et al., 2012).
BGD

10, 16269-16294, 2013

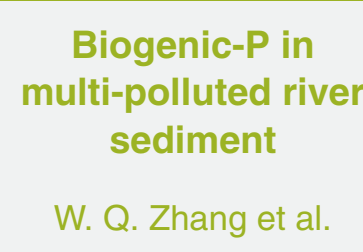

Title Page

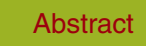

Introduction

Conclusions

Tables

References

Figures

14

$\rightarrow$ I

4

Back

Close

Full Screen / Esc

Printer-friendly Version

Interactive Discussion 
As the economic development and population increase, more and more sewage water was inflow the river. River eutrophication has been a real threat to water quality and freshwater ecology in Northern China (Pernet-Coudrier et al., 2012). Thus, research is urgently needed to improve our understanding of $P$ biogeochemistry and bioavailability 5 in river sediments. The Haihe River is one of the six main river systems of China. It is characterized by a high population density, rapid socioeconomic development and serious water pollution, caused by discharges of industrial and domestic wastewater. Because of the water shortages and the high nutrient $(P)$ inputs, the river is highly eutrophic. Therefore, the objectives of this study were to detect and analyze the $P$ o species in river sediments by $P$ fractionation and ${ }^{31} \mathrm{P}-\mathrm{NMR}$, predict the $\mathrm{P}$ bioavailability and study the relationships between $P$ species in sediment and river water quality. This study will provide useful information to help control $P$ sources and manage river eutrophication.

\section{Materials and methods}

\subsection{Description of study area}

The Haihe River Basin is located in the north of China, and has an area of about $300000 \mathrm{~km}^{2}$ and a population of 145 million. Beijing, Tianjin and many other cities are included in this river basin and its urbanization level is over $45 \%$. The Fuyang River $\left(36^{\circ} 23^{\prime}-38^{\circ} 14^{\prime} \mathrm{N}, 114^{\circ} 19^{\prime}-116^{\circ} 7^{\prime} \mathrm{E}\right)$ is an important tributary of the Haihe River System. It is $402 \mathrm{~km}$ long, and flows through the cities of Hengshui, Handan and Xingtai. The Wagyanggou River, the Shaocunpaigan River and the Xiao River are three important tributaries of the Fuyang River. They receive large amounts of domestic wastewater from Shijiazhuang, the capital of Hebei Province. The Niuwei River is another important tributary of the Fuyang River system that mainly flows through Xingtai. The upper reaches of the Fuyang River are in Handan, which is famous for its steel industry. In 2007, a total of 0.52 billion tons of wastewater was discharged into the river, $50 \%$ of
BGD

10, 16269-16294, 2013

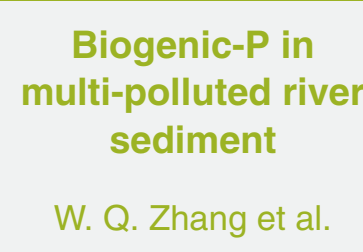

Title Page

Abstract Introduction

Conclusions

Tables

References

Figures

14

$\rightarrow$

4

Back

Close

Full Screen / Esc

Printer-friendly Version

Interactive Discussion 
which was from domestic sewage while the other $50 \%$ came from industrial wastewater. Such discharges of polluted wastewater result in water quality deterioration and, in most rivers, $\mathrm{P}$ is the primary pollutant.

We divided the Fuyang River system into five parts that incorporated the main stem 5 and the four main tributaries. A total of 18 sampling sites were selected throughout the river basin, with 2 to 7 sampling sites in each system. The sites were numbered from 1 to 18 . Sites 1 to 7 were in the Fuyang River, sites 8 and 9 were in the Niuwei River, sites 10 and 11 were in the Xiao River, sites 12 to 15 were in the Wangyanggou River and sites 16 to 18 were in the Shaocunpaigan River (Fig. 1).

\subsection{Sample collection and analysis}

Water quality was monitored trimestral from 2010 to 2012. Sediment samples were collected in July 2012. Three surface (top $5 \mathrm{~cm}$ ) sediment samples were collected at each site using a Peterson grab sampler. Samples taken from the same site were pooled and homogenized to obtain a representative sample. All samples were frozen and stored at $15-18^{\circ} \mathrm{C}$ immediately upon returning from the field. All rivers sampled in this study were publically owned and no specific permits were required for the described field studies. We chose the Fuyang River for sediment sampling because it is heavily polluted with $P$ and it is representative of rivers in northern of China.

The $\mathrm{pH}$ of sediment samples was determined on sediments suspended in deionized water at a sediment: water ratio of $1: 2.5$. Organic matter $(O M)$ in sediments was determined by loss of ignition at $550^{\circ} \mathrm{C}$ for $4 \mathrm{~h}$ (Jensen et al., 1992). Total $\mathrm{Fe}, \mathrm{Al}, \mathrm{Mg}, \mathrm{Mn}$ and $\mathrm{Ca}$ were measured using ICP-OES after digesting sediments with $\mathrm{HNO}_{3}-\mathrm{HCl}-\mathrm{HF}$ (MARSXpress, CEM, USA). Total P (TP) in sediments was determined by $1 \mathrm{~mol} \mathrm{~L}^{-1} \mathrm{HCl}$ extraction $(16 \mathrm{~h})$ after pretreatment for $2 \mathrm{~h}$ at $500^{\circ} \mathrm{C}$. Pi was determined by direct ex25 traction with $1 \mathrm{~mol} \mathrm{~L}^{-1} \mathrm{HCl}(16 \mathrm{~h})$. Po concentrations in the sediments were calculated as the difference between TP and Pi (Aspila et al., 1976). TP in surface water samples was measured using the molybdenum blue method. An annual average TP concentration in surface water was calculated for each site by using monitoring data from 2010 to 16273
BGD

$10,16269-16294,2013$

Biogenic-P in

multi-polluted river sediment

W. Q. Zhang et al.

Title Page

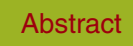

Introduction

Conclusions References

Tables Figures

14 $\rightarrow 1$

4

Back

Close

Full Screen / Esc

Printer-friendly Version

Interactive Discussion 
2012. Three replicates were analyzed for each sampling event, from which the mean value was calculated.

\subsection{Phosphorus fractionations}

The $\mathrm{P}$ fractionation procedure was based on the method of Hieltjes-Lijklema (Hieltjes 5 and Lijklema, 1980). This fractionation procedure separates the $\mathrm{P}$ in the sediment into five groups: (1) $P$ in porewater and loosely sorbed $P$ were extracted with $1 \mathrm{M} \mathrm{KCl}$ at room temperature for $1 \mathrm{~h}(\mathrm{KCl}-\mathrm{P})$, and then the sediment was shaking with $0.1 \mathrm{M} \mathrm{NaOH}$ for $17 \mathrm{~h}$ at room temperature, the extractant was determined using molybdenum blue method before $(\mathrm{NaOH}-\mathrm{Pi})$ and after $(\mathrm{NaOH}-\mathrm{TP})$ digestion by $\mathrm{K}_{2} \mathrm{~S}_{2} \mathrm{O}_{8}$. (2) The $\mathrm{NaOH}$ -

$10 \mathrm{Pi}$ was the $\mathrm{P}$ adsorbed to iron and manganese, and the difference between $\mathrm{NaOH}-\mathrm{TP}$ and $\mathrm{NaOH}-\mathrm{Pi}$ was (3) $\mathrm{NaOH}-\mathrm{Po}$, which was assumed to be organic $\mathrm{P}$ and bacteriaincorporated $\mathrm{P}$ (Ahlgren et al., 2005). Finally, (4) $\mathrm{H}_{2} \mathrm{SO}_{4}$ was used for extracting the $\mathrm{P}$ mostly apatite, which was stable withhold in the sediment $\left(\mathrm{H}_{2} \mathrm{SO}_{4}-\mathrm{P}\right)$. (5) The Res-P fraction was the difference between TP in sediment $(\mathrm{HCl}$ extracted- $\mathrm{P})$ and the sum of $15 \mathrm{KCl}-\mathrm{P}, \mathrm{NaOH}-\mathrm{TP}$ and $\mathrm{H}_{2} \mathrm{SO}_{4}-\mathrm{P}$. The $\mathrm{P}$ concentration in all the extracts was estimated colorimetrically using the method of Murphy and Riley (Murphy and Riley, 1962).

\section{$2.4 \mathrm{NaOH}-\mathrm{EDTA}$ extraction and ${ }^{31} \mathrm{P}-\mathrm{NMR}$ analysis}

Sediment samples $(5.0 \mathrm{~g})$ were pre-treated for $16 \mathrm{~h}$ at room temperature with a $50 \mathrm{~mL}$ solution of $0.05 \mathrm{~mol} \mathrm{~L}^{-1}$ EDTA and $0.25 \mathrm{~mol} \mathrm{~L}^{-1} \mathrm{NaOH}$ (Turner et al., 2003b). An aliquot of the $\mathrm{NaOH}$-EDTA extract was used for $\mathrm{Pi}$ (Pi in $\mathrm{NaOH}$-EDTA) and TP (TP in $\mathrm{NaOH}$ EDTA) analyses using the molybdenum blue method before and after digestion with $\mathrm{K}_{2} \mathrm{~S}_{2} \mathrm{O}_{8}$. Po in the $\mathrm{NaOH}$-EDTA extract was calculated as the difference between these two fractions. The remaining solution was frozen and lyophilized to be used for ${ }^{31} \mathrm{P}$ NMR analysis. Freezing the extracts has been shown not to alter the $\mathrm{P}$ composition 25 (Hupfer et al., 1995, 2004).
BGD

10, 16269-16294, 2013

\section{Biogenic-P in \\ multi-polluted river sediment \\ W. Q. Zhang et al.}

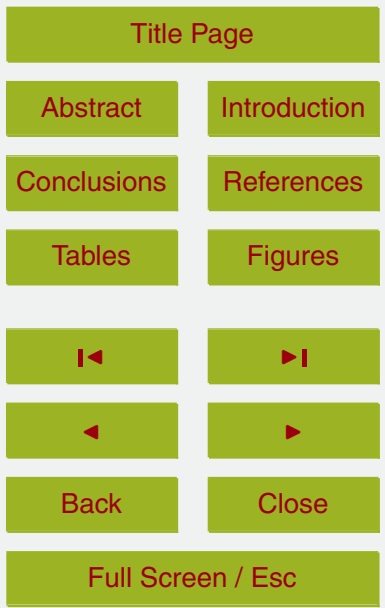

Printer-friendly Version

Interactive Discussion 
The lyophilized $\mathrm{NaOH}$-EDTA extract $(0.3 \mathrm{~g})$ was re-dissolved in $0.6 \mathrm{~mL} \mathrm{D}_{2} \mathrm{O}$ and $0.1 \mathrm{~mL} 10 \mathrm{molL}^{-1} \mathrm{NaOH}$, ultrasonicated for $30 \mathrm{~min}$ and then equilibrated for $5 \mathrm{~min}$. $2 \%(\mathrm{v} / \mathrm{v})$ of bicarbonate buffered dithionite $\left(0.11 \mathrm{MNaHCO}_{3}+0.11 \mathrm{MNa}_{2} \mathrm{~S}_{2} \mathrm{O}_{4}\right)$ was added to the extract to reduce interference from paramagnetic ions, such as Fe and $5 \mathrm{Mn}$. The supernatants were centrifuged for $15 \mathrm{~min}$ at $14000 \mathrm{rpm}$ and transferred to $5 \mathrm{~mm}$ NMR tubes. Solution ${ }^{31} \mathrm{P}-\mathrm{NMR}$ spectra were obtained using a Bruker $400 \mathrm{MHz}$ spectrometer (Bruker, Billerica, MA, USA) operating at $129.53 \mathrm{MHz}$ at $25^{\circ} \mathrm{C}$. We used a $90^{\circ} \mathrm{C}$ observe pulse, a relaxation delay of $2 \mathrm{~s}$ and an acquisition time of $0.6 \mathrm{~s}$ (Liu et al., 2009). Spectra were collected with around 20000 scans (Beijing NMR Center, 10 Beijing, China). Chemical shifts were recorded relative to an $85 \% \mathrm{H}_{3} \mathrm{PO}_{4}$ standard $(\delta=0 \mathrm{ppm})$. Signals were assigned to $\mathrm{P}$ species based on data in the literature (CadeMenun, 2005; Turner et al., 2003a). The peak area was determined by visual inspection and an automated peak analysis tool. For the different $P$ species areas, the contribution of each $P$ compound group (ortho-P, phon- $P$, pyro- $P$, mono-P, diester-P (DNA-P 15 and lipid-P) and ploy-P) was calculated relative to the TP in the $\mathrm{NaOH}$-EDTA extraction, determined by molybdenum blue method. The author verified the chemical shifts of $\mathrm{P}$ compounds by carrying out spike experiments using known compounds to assign peaks (such as $\mathrm{Na}_{4} \mathrm{P}_{2} \mathrm{O}_{7} \cdot 10 \mathrm{H}_{2} \mathrm{O}$ ) (Wang and Pant 2010).

\subsection{Data analysis}

20 The Kolmogorov-Smirnov test for normality of the data was applied to determine if the data were normally distributed and non-normal data were log-transformed. Spearman's rho was analyzed the data that could not be normally transformed, while those that normally distributed data were calculated by Pearson's correlation coefficient. Correlation plots were obtained using Microsoft Excel. The probability levels of the correlations 25 were performed using OriginPro 8.0.
BGD

10, 16269-16294, 2013
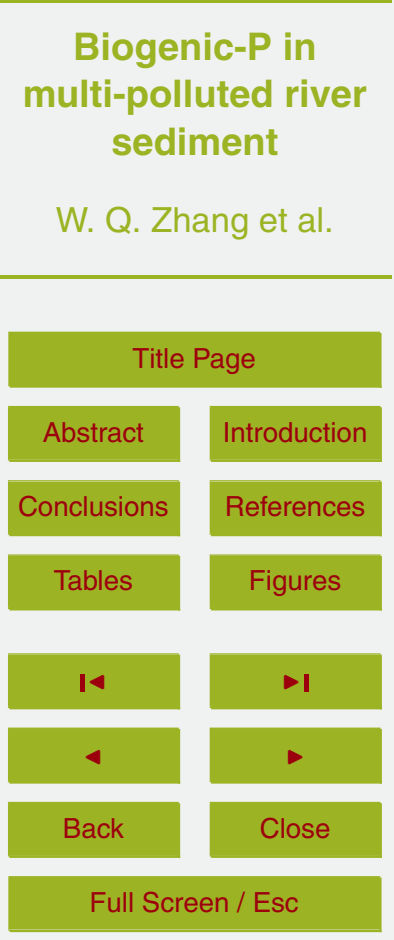

Printer-friendly Version

Interactive Discussion 


\section{Results}

\subsection{Phosphorus in surface water and sediment samples}

Sediment properties are shown in Table 1. For the 18 sediments, the concentration of TP varied greatly, and ranged from 462 to $9829 \mathrm{mg} \mathrm{kg}^{-1}$. The average TP concentra5 tion was $2448 \mathrm{mg} \mathrm{kg}^{-1}$ and sampling points $1,2,3,4,6,9,1012,15$ and 18 had TP concentrations higher than $1000 \mathrm{mg} \mathrm{kg}^{-1}$. Pi was the main $\mathrm{P}$ fraction. Po concentrations ranged from 22 to $2040 \mathrm{mg} \mathrm{kg}^{-1}$, accounting for between 4.8 and $51.3 \%$ of TP. OM content varied with TP concentrations. The average OM content was $8.78 \%$ and ranged from 1.99 to $25.19 \%$. The $\mathrm{pH}$ in sediments ranged from 6.69 to 8.53 . The concentrations of other metals in the sediments were as follows: total Al concentrations ranged from 5.51 to $35.19 \mathrm{~g} \mathrm{~kg}^{-1}$, total Ca from 11.17 to $25.8 \mathrm{~g} \mathrm{~kg}^{-1}$, total Fe from 30.06 to $57.59 \mathrm{~g} \mathrm{~kg}^{-1}$, total $\mathrm{Mg}$ from 2.95 to $5.58 \mathrm{~g} \mathrm{~kg}^{-1}$ and total $\mathrm{Mn}$ from 0.30 to $0.65 \mathrm{~g} \mathrm{~kg}^{-1}$. The ratio of TC to TP in the sediments ranged from 14.37 to 51.40 .

Total P and Soluble Reactive Phosphorus (SRP) in surface water samples also var15 ied greatly, ranging from 0.17 to $7.29 \mathrm{mg} \mathrm{kg}^{-1}$ and 0.06 to $6.44 \mathrm{mg} \mathrm{kg}^{-1}$ respectively. Higher TP and SRP concentrations were found at sites where TP concentrations in sediments were also high.

\subsection{Phosphorus fractionation in sediments}

The concentrations and percentages of $P$ fractions in sediments are shown in Fig. 2. Sediment $\mathrm{P}$ was mainly composed of $\mathrm{H}_{2} \mathrm{SO}_{4}-\mathrm{P}$ and $\mathrm{NaOH}-\mathrm{Pi} . \mathrm{H}_{2} \mathrm{SO}_{4}-\mathrm{P}$ concentrations ranged from 344.4 to $2941.7 \mathrm{mg} \mathrm{kg}^{-1}$, and had a relative contribution of between 20.2 and $74.5 \%$ to TP, while concentrations of $\mathrm{NaOH}-\mathrm{Pi}$ ranged from 54.4 to $5749.2 \mathrm{mg} \mathrm{kg}^{-1}$ and had a relative contribution of 7.6 to $65.1 \%$ to TP. Res-P ranged from 33.6 to $1257.9 \mathrm{mg} \mathrm{kg}^{-1}$, and had a relative contribution of 1.4 to $18.8 \%$. The concentrations of $\mathrm{NaOH}-\mathrm{Po}$ and $\mathrm{KCl}-\mathrm{P}$ were lower than those of the other fractions. $\mathrm{NaOH}-\mathrm{Po}$ ranged from 0.3 to $243.9 \mathrm{mg} \mathrm{kg}^{-1}$, and had a relative contribution of between 0.1 and $5.2 \%$

\section{Biogenic-P in \\ multi-polluted river sediment \\ W. Q. Zhang et al.}

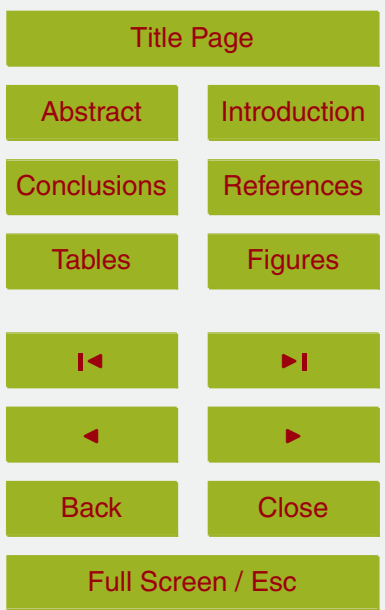

Printer-friendly Version

Interactive Discussion 
to $\mathrm{TP}$, while $\mathrm{KCl}-\mathrm{P}$ ranged from 1.2 to $31.0 \mathrm{mg} \mathrm{kg}^{-1}$, and had a relative contributions of between 0.1 and $2.1 \%$ to TP. The rank order and average relative proportions of the $\mathrm{P}$ fractions were as follows (the proportion was based on the average proportion of the KCl-P): $\mathrm{H}_{2} \mathrm{SO}_{4}-\mathrm{P}(69.7 \%)>\mathrm{NaOH}-\mathrm{Pi}(47.5 \%)>$ Res-P $(15.9 \%)>\mathrm{NaOH}-\mathrm{Po}$ $5 \quad(2.9 \%)>\mathrm{KCl}-\mathrm{P}(1.0 \%)$.

\section{3 ${ }^{31} \mathrm{P}-\mathrm{NMR}$ spectra of $\mathrm{NaOH}-\mathrm{EDTA}$ extracts of sediments}

The NMR spectra of the surface sediments are shown in Fig. 3. Seven P compounds were detected in the $\mathrm{NaOH}-\mathrm{EDTA}$ extract by ${ }^{31} \mathrm{P}-\mathrm{NMR}$. All NMR-spectra showed peaks in the area of phon-P (12 to $23 \mathrm{ppm}$ ), ortho-P (6 to $7 \mathrm{ppm}$ ), mono-P (4 to $6 \mathrm{ppm}$ ), lipid-P 10 (1 to $3 \mathrm{ppm})$, DNA-P (0 ppm), pyro-P ( -3.5 to $-4.5 \mathrm{ppm})$ and poly-P ( -17 to $-19 \mathrm{ppm})$ (Cade-Menun et al., 2006). Mono-P was the main Po form. Lipid-P and phon-P were not detected in the sediments from sites $7,8,13$ and $1,5,7,8,17$, respectively.

The concentrations of the various $P$ compound groups in surface sediments are presented in Table 2. Sediment TP in the $\mathrm{NaOH}$-EDTA extracts ranged from 179.7 to $155712.9 \mathrm{mg} \mathrm{kg}^{-1}$, which represented recovery of between 27.2 and $87.1 \%$ of the TP in the sediments. Po in the $\mathrm{NaOH}$-EDTA ranged from 15.4 to $2578.3 \mathrm{mg} \mathrm{kg}^{-1}$, representing a recovery ranging from 30.0 to $73.0 \%$. Ortho-P was the main component of TP in the sediments. Its concentration in the $\mathrm{NaOH}$-EDTA extract from sediments ranged from 140.8 to $4061.6 \mathrm{mg} \mathrm{kg}^{-1}$, accounting for 45.2 to $92.4 \%$ of TP in the $\mathrm{NaOH}$-EDTA extracts. Pyro-P ranged from 0.3 to $44.2 \mathrm{mg} \mathrm{kg}^{-1}$, accounting for 0.1 to $6.6 \%$ of the TP in the $\mathrm{NaOH}$-EDTA extracts. Poly-P was only detected in sediments from site 1 , and had a concentration of $0.2 \mathrm{mg} \mathrm{kg}^{-1}$ and a relative contribution of $0.04 \%$ to TP in the $\mathrm{NaOH}-\mathrm{EDTA}$ extracts. Mono-P was the main component of Po. Its concentrations ranged from 13.1 to $2220.9 \mathrm{mg} \mathrm{kg}^{-1}$, accounting for between 6.6 and $45.7 \%$ of TP in 25 the sediment extracts. Lipid-P ranged from 0 to $141.1 \mathrm{mg} \mathrm{kg}^{-1}$, accounting for 0 to $2.7 \%$ of the TP in the sediment extracts. DNA-P ranged from 0.5 to $124.2 \mathrm{mg} \mathrm{kg}^{-1}$, account-
BGD

10, 16269-16294, 2013

Biogenic-P in

multi-polluted river sediment

W. Q. Zhang et al.

Title Page

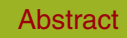

Introduction

Conclusions

References

Tables

Figures

14

$\rightarrow$

4

Back

Close

Full Screen / Esc

Printer-friendly Version

Interactive Discussion 
ing for 0.3 to $3.9 \%$ of the TP in the NaOH-EDTA extracts. The levels of phon-P ranged from 0 to $141.4 \mathrm{mg} \mathrm{kg}^{-1}$, accounting for up to $3.3 \%$ of TP in the $\mathrm{NaOH}$-EDTA extracts.

\section{Discussion}

\subsection{Sediment $\mathbf{P}$ pollution}

5 The Haihe River basin has high population, economic and agricultural growth rates, and as a result, faces increasingly severe water-related issues. Human and industrial water consumption and irrigation of intensely farmed land has led to water shortages. Meanwhile, the nutrient concentrations in this region's rivers have increased dramatically in the past $40 \mathrm{yr}$ (Pernet-Coudrier et al., 2012). The average and maximum TP concentra10 tions in surface water were 1.68 and $7.29 \mathrm{mg} \mathrm{L}^{-1}$, while the average and maximum SRP concentrations were 1.21 and $6.44 \mathrm{mgL}^{-1}$, respectively. All of these values far exceed the water quality criteria for both the USA $\left(0.1 \mathrm{mgL}^{-1}\right.$ : EPA 440/5-86-001) (US EPA, 1986) and China (0.4 $\mathrm{mg} \mathrm{L}^{-1}$ : GB3838-2002) (National Standard of the People's Republic of China, GB3838-2002), which means that the water is unsuitable for any use.

15 Sediment TP concentrations ranged from 462 to $9829 \mathrm{mg} \mathrm{kg}^{-1}$. The average sediment TP concentration was $2448 \mathrm{mg} \mathrm{kg}^{-1}$ and TP concentrations exceeded $1000 \mathrm{mg} \mathrm{kg}^{-1}$ at $55.6 \%$ of sampling sites. Because of the excessive $P$ inputs, significant amounts of $P$ have accumulated in the river sediments, and exceed what has been reported for Lake Taihu (Bai et al., 2009), Lake Erken (Ahlgren et al., 2005), Bronx River (Wang and 20 Pant, 2010), Lake Kasumigaura (Shinohara et al., 2012) and various other sediments (Liu et al., 2009).

The ratio of TC to TP $(\mathrm{C} / \mathrm{P})$ gives information on the origin of the $\mathrm{OM}$ and the Po biogeochemical cycle (Meyers, 1994). A high C/P value implies $\mathrm{P}$ losses. Po degrades when $\mathrm{OM}$ degrades. A low $\mathrm{C} / \mathrm{P}$ value means that the nutrient input is mainly from human activities and that $P$ is accumulating in the sediments. In this study, a negative correlation between the C/P values and TP in the sediments indicated that the high TP
10, 16269-16294, 2013

Biogenic-P in

multi-polluted river sediment

W. Q. Zhang et al.

Title Page

Abstract Introduction

Conclusions References

Tables Figures

14 $\rightarrow 1$

4

Back

Close

Full Screen / Esc

Printer-friendly Version

Interactive Discussion 
concentrations were mainly due to anthropogenic inputs. Correlations between TP and $\mathrm{OM}\left(R_{\mathrm{TP}-\mathrm{OM}}^{2}=0.87\right)$ and Po and OM $\left(R_{\mathrm{Po-OM}}^{2}=0.89\right)$ indicated that the P and OM in the sediments are homologous, and that the majority of Po was most likely associated with OM, such as fulvic and humic acids (Bai et al., 2009). There was little variation between

5 TP and $P o$ in river reaches where there were lower $P$ inputs from point source pollution (Fig. 4). High values of TP and Po appeared in the Fuyang River. The concentrations of TP and Po were 9829 and $3787 \mathrm{mg} \mathrm{kg}^{-1}$ at sampling point 4, the location of the Aixinzhuang Dam. The dam interferes with river flow and reduces velocity, which results in sediment $P$ accumulation at the dam wall. Accumulation of large amounts of $P$ in the 10 sediments is a vital $P$ source to surface water that will induce ongoing eutrophication in this river system even if external inputs are reduced.

\section{2 ${ }^{31}$ P-NMR spectroscopy and P fractions}

In this study, three methods were used to extract Po from river sediments: (1) $\mathrm{NaOH}$ alone, (2) $\mathrm{NaOH}$ followed by $\mathrm{BD}$, EDTA and $\mathrm{Na}_{2} \mathrm{~S}_{2} \mathrm{O}_{4}$ pretreatments and (3) vari15 ous ratios of $\mathrm{NaOH}-\mathrm{EDTA}$ (unpublished data). Results showed that the proportionoptimized $\mathrm{NaOH}$-EDTA extracted more Po. For this study therefore, we chose $0.25 \mathrm{M} \mathrm{NaOH}+50 \mathrm{mMEDTA}$ as the extract. The $\mathrm{NaOH}$ guarantees a high recovery rate of Po, while EDTA can prevent poly-P hydrolysis during extraction and can reduce the concentration of paramagnetic ions, such as Fe and Mn (Turner et al., 2005; Hupfer 20 et al., 1995; Cade-Menun et al., 2002). TP and Po in NaOH-EDTA were positively related with TP and Po in sediments, with corresponding recoveries of $27-87 \%$ and 30 $73 \%$, respectively. These results were similar to Po recovery results from other studies (Table 3). The difference between the results of Po analyses by colorimetry and ${ }^{31} \mathrm{P}$ NMR ranged from -45.10 to $75.17 \mathrm{mg} \mathrm{kg}^{-1}$. Bedrock et al. (1994) reported that some 25 macromolecular Po compounds were not detected by ${ }^{31} \mathrm{P}-\mathrm{NMR}$, so colorimetry results for Po tend to be higher than those from ${ }^{31} \mathrm{P}-\mathrm{NMR}$ analyses. To avoid the EDTA interference, the colorimetry extracts were diluted 100-fold (Turner, 2004). The differences in

BGD

10, 16269-16294, 2013

Biogenic-P in

multi-polluted river sediment

W. Q. Zhang et al.

Title Page

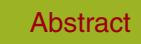

Introduction

Conclusions

References

Tables

Figures

14

$\rightarrow 1$

4

Back

Close

Printer-friendly Version

Interactive Discussion 
the Po concentrations from the two analyses methods (i.e. colorimetry and ${ }^{31} \mathrm{P}-\mathrm{NMR}$ ) are due to the complex physical and chemical properties of the sediments in the rivers.

Orthophosphate was the dominant $\mathrm{P}$ fraction in $\mathrm{NaOH}$-EDTA extracts of the river sediments. This could be because of the continuous inputs of either industrial and do5 mestic wastewater, or non-point pollution from agriculture. A proportion of the ortho-P may also be the result of in-river transformations. For example, some Po that entered the river systems may have been hydrolyzed to ortho-P by phosphatase (Turner et al., 2006). Additionally, pyro-P, as a kind of ortho-P, partially originates from ester or poly- $P$ that hydrolyzes during alkaline extraction (Hupfer et al., 1995). The poly-P fraction was 10 only detected at site 1 and its concentration was low, which indicates that poly- $P$ was not an important $P$ form in the sediments. Poly- $P$ was the most labile $P$ form in the sediments, and has a short half-life (2.0-6.0 yr, supernatant and precipitate) (Reitzel et al., 2007). Orthophosphate monoesters were the main form of Po in the sediments. It represents a wide range of important Po compounds, such as inositol phosphate and sugar phosphates (Zhang et al., 2009), and has a long half-life in sediments (23yr) (Ahlgren et al., 2005). The ortho-P may originated from sediment (e.g. Inositol hexaphosphate) or the degradation of diesters. Inositol hexaphosphate was considered to be the dominant compound of mono-P by other researchers, who found that it represented more than $50 \%$ of total Po in the soil (Anderson, 1961). In this study, we also found that the residual $\mathrm{P}$ fraction was positively correlated with the mono- $\mathrm{P}$ and phon- $\mathrm{P}$ fractions, which ranged from 6.57 to $29.20 \%$ of TP in the NaOH-EDTA extracts $\left(R^{2}=0.79\right.$, $p<0.01)$. Orthophosphate diesters were a form of labile $P$ in the sediments. It has a half-life of $21 \mathrm{yr}$, and is a mixture of compounds such as DNA-P, lipid-P and teichoic$\mathrm{P}$ (Ahlgren et al., 2005; Cade-Menun, 2005; Turner et al., 2003b). A positive correlation 25 between diester- $\mathrm{P}$ in $\mathrm{NaOH}-\mathrm{EDTA}$ and the $\mathrm{NaOH}-\mathrm{Po}$ in sediment by $\mathrm{P}$ fractionation indicated that the $\mathrm{NaOH}-\mathrm{Po}$ by $\mathrm{P}$ fractionation was mostly labile $\mathrm{P}\left(R^{2}=0.77, p<0.01\right)$. DNA-P and lipid-P were detected in the sediments of the Fuyang River. DNA-P originates from the decomposition of bacterial DNA and phytoplankton. The high concentration of DNA-P at sites with severe $P$ pollution indicates that hydrophytes occurred
BGD

10, 16269-16294, 2013
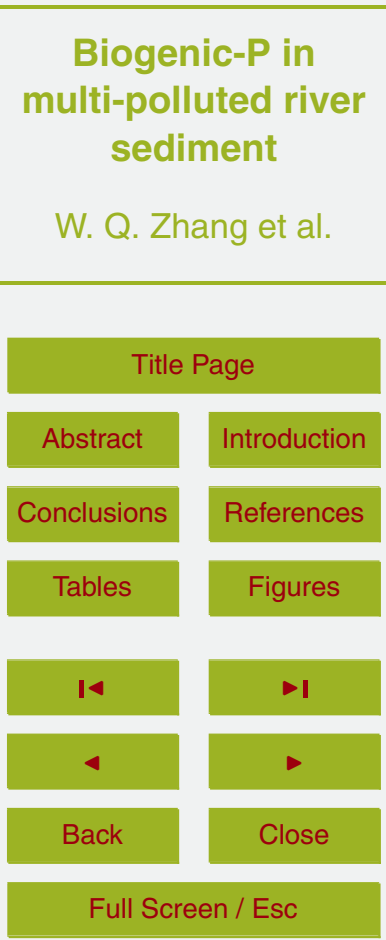

Printer-friendly Version

Interactive Discussion 
at those places. Lipid-P also indicated that there was microbial activity in the water and sediment and this fraction was a biomarker of OM transformations (Meyers and Ishiwatari, 1993; Lu and Meyers, 2009).

The positive correlation between $\mathrm{NaOH}-\mathrm{Pi}$ (as determined by $\mathrm{P}$ fractionation) and $5 \mathrm{NaOH}-\mathrm{Fe}$ and $\mathrm{NaOH}-\mathrm{Al}$ indicated that the sediment $\mathrm{P}$ immobilization potential was controlled by Fe and Al hydroxides $\left(R^{2}=0.88, p<0.01\right)$ (Kopáèek et al., 2005). Liu reported that BD-Fe and $\mathrm{NaOH}-\mathrm{Al}$ together explained $68 \%$ of the variability in the maximum sorption capacity of sediment (Liu et al., 2009). $\mathrm{P}$ fractionation and ${ }^{31} \mathrm{P}-\mathrm{NMR}$ analysis showed that $35 \%$ of $\mathrm{Pi}$ was labile $\mathrm{P}$, including $\mathrm{KCl}-\mathrm{P}$ and $\mathrm{NaOH}-\mathrm{Pi}(\mathrm{Fe}-\mathrm{P}$ and 10 Al-P). Biogenic-P, which was considered molybdenum-non-reactive $P$ in the $\mathrm{NaOH}$ extract, accounted for $24 \%$ in the sediments (Fig. 5). There is a high risk of release of both labile $P$ and biogenic- $P$ to the water column, thereby leading to water eutrophication (Li et al., 2013).

\subsection{Biogenic $P$ species and water quality}

15 Water quality monitoring data of the Fuyang River shows that the $\mathrm{P}$ concentrations are increasing (unpublished data), and that the average $\mathrm{P}$ concentrations in river water are higher than the environmental quality standards for surface water in China (National Standard of the People's Republic of China, GB3838-2002.). Decreased rainfall and increased water consumption have led to water shortages. Increases in nutrients $(P)$ 20 and decreases in water availability have resulted in the water quality getting worse. Fortunately, the government has realized the severity of the situation and has adopted measures to improve water quality. The sediment, as a store, has the capacity to adsorb $\mathrm{P}$, and this adsorbed $\mathrm{P}$ may be released from the sediment into the water column even if external inputs are reduced. Apart from ortho- $P$, biogenic $P$ is an important source 25 of $\mathrm{P}$ in surface water. Biogenic $\mathrm{P}$ includes $\mathrm{Po}$, poly- $\mathrm{P}$ and pyro- $\mathrm{P}$, which were analyzed as molybdenum-non-reactive $\mathrm{P}$ in the $\mathrm{NaOH}$ extract (Ahlgren et al., 2005; Shinohara et al., 2012). Biogenic $P$ could be released from the sediments under redox conditions and could induce water eutrophication (Ahlgren et al., 2006). The positive relationship 16281
BGD

10, 16269-16294, 2013

\section{Biogenic-P in \\ multi-polluted river sediment \\ W. Q. Zhang et al.}

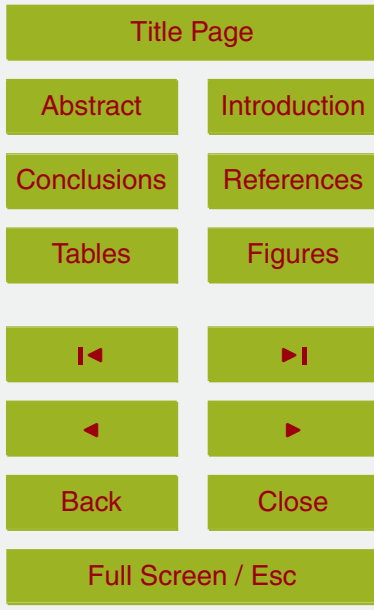

Printer-friendly Version

Interactive Discussion 
between biogenic- $\mathrm{P}$ and TP in the water column indicates that the biogenic- $\mathrm{P}$ compounds could be released into surface water and could support hydrophyte growth. There was also a positive relationship between mono-P and TP in the water column $\left(R^{2}=0.743, p<0.01\right)$. Mono-P comprises a wide range of Po compounds, such as 5 inositol hexaphosphoric acid, which can be combined with multivalent ions to form a precipitate, but studies have reported that it can also be mineralized into $\mathrm{Pi}$ under anaerobic conditions (Suzumura and Kamatani, 1993). Lipid-P, as a kind of diester-P, is liable $\mathrm{Po}$ in the sediment, and can be mineralized to $\mathrm{Pi}$ and utilized by hydrophytes. There was no correlation between TP in the water and either pyro-P or DNA-P, both 10 of which should be more labile than mono-P, as indicated by their shorter half-life in sediments. The absence of any correlation may have been because these forms disappeared during the $\mathrm{NaOH}-\mathrm{EDTA}$ extraction process. The lipid-P may be hydrolyzed under strong alkaline extractions (Turner et al., 2003a; McDowell and Stewart, 2005).

\section{Conclusions}

15 This research has used $\mathrm{P}$ fractionation and ${ }^{31} \mathrm{P}-\mathrm{NMR}$ to provide an insight into the $P$ species and distribution of $P$ pollution in sediments of the heavily polluted and water scarce Fuyang River and their effects. Results show that the river sediments have accumulated significant amounts of $\mathrm{Pi}$ and $\mathrm{Po}$. The rank order of the $\mathrm{P}$ fractions was as follows: $\mathrm{H}_{2} \mathrm{SO}_{4}-\mathrm{P}>\mathrm{NaOH}-\mathrm{Pi}>$ Res- $\mathrm{P}>\mathrm{NaOH}-\mathrm{Po}>\mathrm{KCl}-\mathrm{P}$, and their average rela20 tive proportions were $69.7: 47.5: 15.9: 2.9: 1.0$. Seven $P$ compounds were detected in $\mathrm{NaOH}-\mathrm{EDTA}$ extract from the ${ }^{31} \mathrm{P}-\mathrm{NMR}$ analysis. Ortho-P (45.2-92.4\%) and mono$P(6.6-45.7 \%)$ were the dominant forms, while smaller amounts of pyro-P $(0.1-6.6 \%)$, DNA-P (0.3-3.9\%), phon-P (0-3.3\%), lipid-P (0-2.7\%) and poly-P (0-0.04\%) were found in the surface sediments. Results of the $\mathrm{P}$ fractionation and ${ }^{31} \mathrm{P}-\mathrm{NMR}$ analysis showed that $35 \%$ of $\mathrm{Pi}$ was labile $\mathrm{P}$, and included $\mathrm{KCl}-\mathrm{P}$ and $\mathrm{NaOH}-\mathrm{Pi}$ (Fe-P and Al-P). Biogenic- $P$ accounted for $24 \%$ of $P$ in the sediments. Analysis of the relationships between $\mathrm{P}$ species and water quality indicated that $\mathrm{Po}$ compounds could be mineralized
BGD

10, 16269-16294, 2013

\section{Biogenic-P in \\ multi-polluted river sediment \\ W. Q. Zhang et al.}

Title Page

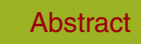

Introduction

Conclusions

Tables

References

Figures

14

$\rightarrow 1$

4

Back

Close

Full Screen / Esc

Printer-friendly Version

Interactive Discussion 
to ortho-P. This fraction is potentially bioavailable and, on release to the water column, could support the ongoing growth of aquatic organisms, leading to algal blooms.

Acknowledgements. We thank Jingxin Yang and Hongwei Li for ${ }^{31} \mathrm{P}-\mathrm{NMR}$ analysis (Beijing Nuclear Magnetic Resonance Center). This work was supported by the National Natural Science

5 Foundation of China (Grant No. 20907067 and 21107126) and the National Water Pollution Control and Management Technology Major Projects of China (2012ZX07203-006).

\section{References}

Ahlgren, J., Tranvik, L., Gogoll, A., Waldeback, M., Markides, K., and Rydin, E.: Sediment depth attenuation of biogenic phosphorus compounds measured by ${ }^{31} \mathrm{P}$ NMR, Environ. Sci. Tech10 nol., 39, 867-872, 2005.

Ahlgren, J., Reitzel, K., Tranvik, L., Gogoll, A., and Rydin, E.: Degradation of organic phosphorus compounds in anoxic Baltic Sea sediments: a ${ }^{31} \mathrm{P}$ nuclear magnetic resonance study, Limnol. Oceanogr., 51, 2341-2348, 2006.

Anderson, G.: A partial fractionation of alkali-solution organic phosphate, Journal Soil Sci., 12, $15 \quad 276-285,1961$.

Aspila, K. I., Agemian, H., and Chau, A. S. Y.: A semi-automated method for the determination of inorganic organic and total phosphate in sediments, Analyst, 101, 187-197, 1976.

Bai, X. L., Ding, S. M., Fan, C. X., Liu, T., Shi, D., and Zhang, L.: Organic phosphorus species in surface sediments of a large shallow, eutrophic lake, Lake Taihu, China, Environ. Pollut., $20 \quad$ 157, 2507-2513, 2009.

Bedrock, C. N., Cheshire, M. V., Chudek, J. A., Goodman, B. A., and Shand, C. A.: Use of ${ }^{31}$ PNMR to study the forms of phosphorus in peat soils, Sci. Total. Environ., 152, 1-8, 1994.

Cade-Menun, B. J.: Characterizing phosphorus in environmental and agricultural samples by

${ }^{31} \mathrm{P}$ nuclear magnetic resonance spectroscopy, Talanta, 66, 359-371, 2005.

25 Cade-Menun, B. J., Liu, C. W., Nunlist, R., and McColl, J. G.: Soil and litter phosphorus-31 nuclear magnetic resonance spectroscopy: extractants, metals, and phosphorus relaxation times, J. Environ. Qual., 31, 457-465, 2002.

Biogenic-P in

multi-polluted river

sediment

W. Q. Zhang et al.

Title Page

Abstract

Conclusions

Tables

14

4

Back

Introduction

References

Figures

$\rightarrow 1$

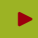

Close

\section{Full Screen / Esc}

Printer-friendly Version

Interactive Discussion 
Cade-Menun, B. J., Benitez-Nelson, C. R., Pellechia, P., and Paytan, A.: Refining ${ }^{31} \mathrm{P}$ nuclear magnetic resonance spectroscopy for marine particulate samples: storage conditions and extraction recovery, Mar. Chem., 97, 293-306, 2005.

Cade-Menun, B. J., Navaratnam, J. A., and Walbridge, M. R.: Characterizing dissolved and particulate phosphorus in water with ${ }^{31} \mathrm{P}$ nuclear magnetic resonance spectroscopy, Environ. Sci. Technol., 40, 7874-7880, 2006.

Hieltjes, A. H. M. and Lijklema, L.: Fractionation of inorganic phosphorus in calcareous sediments, J. Environ. Qual., 9, 405-407, 1980.

Hupfer, M., Gächter, R., and Ruegger, H.: Polyphosphate in lake sediments: ${ }^{31} \mathrm{P}$ NMR spec10 troscopy as a tool for its identification, Limnol. Oceanogr., 40, 610-617, 1995.

Hupfer, M., Rübe, B., and Schmieder, P.: Origin and diagensis of polyphosphate in lake sediments: a ${ }^{31}$ P-NMR study, Limnol. Oceanogr., 49, 1-10, 2004.

Ingall, E. D., Schroeder, P. A., and Berner, R. A.: The nature of organic phosphorus in marine sediments: new insights from ${ }^{31}$ P NMR, Geochim. Cosmochim. Ac., 54, 2617-2620, 1990.

15 Jensen, H. S., Kristensen, P., Jeppesen, E., and Skytthe, A.: Iron: phosphorus ratio in surface sediment as an indicator of phosphate release from aerobic sediments in shallow lakes, Hydrobiologia, 235/236, 731-743, 1992.

Kopáèek. J., Borovec, J., Hejzlar, J., Ulrich, K., Norton, S. A., and Amirbahman, A.: Aluminum control of phosphorus sorption by lake sediments, Environ. Sci. Technol., 39, 8784-8789, 2005.

Li, M., Whelan, M. J., Wang, G. Q., and White, S. M.: Phosphorus sorption and buffering mechanisms in suspended sediments from the Yangtze Estuary and Hangzhou Bay, China, Biogeosciences, 10, 3341-3348, doi:10.5194/bg-10-3341-2013, 2013.

Liu, J. Y., Wang, H., Yang, H. J., Ma, Y. J., and Cai, O. C.: Detection of phosphorus species in sediments of artificial landscape lakes in China by fractionation and phosphorus-31 nuclear magnetic resonance spectroscopy, Environ. Pollut., 157, 49-56, 2009.

$\mathrm{Lu}, \mathrm{Y} . \mathrm{H}$. and Meyers, P. A.: Sediment lipid biomarkers as recorders of the contamination and cultural eutrophication of Lake Erie, 1909-2003, Org. Geochem., 40, 912-921, 2009.

McDowell, R. W. and Stewart, I.: Peak assignments for phosphorus-31 nuclear magnetic resonance spectroscopy in $\mathrm{pH}$ range 5-13 and their application in environmental samples, Chem. Ecol., 21, 211-226, 2005.

Meyers, P. A.: Preservation of elemental and isotopic source identification of sedimentary organic matter, Chem. Geol., 114, 289-302,1994.
BGD

10, 16269-16294, 2013

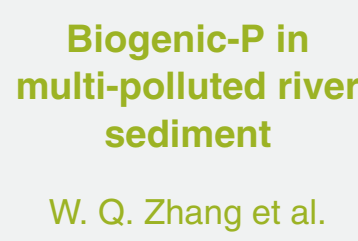

Title Page

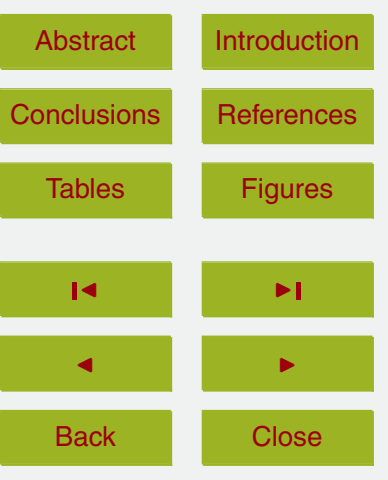

Full Screen / Esc

Printer-friendly Version

Interactive Discussion 
Meyers, P. A. and Ishiwatari, R.: Lacustrine organic geochemistry-an overview of indicators of organic-matter sources and diagenesis in lake-sediments, Org. Geochem., 20, 867-900, 1993.

Murphy, J. and Riley, J. P.: A modified single solution method for the determination of phosphate in nature waters, Anal. Chim. Acta, 27, 31-36, 1962.

National Standard of People's Republic of China, Environmental quality standards for surface water, GB3838-2002, 2002.

Newman, R. H. and Tate, K. R.: Soil phosphorus characterization by ${ }^{31} \mathrm{P}$ nuclear magnetic resonance, Commun. Soil Sci. Plan., 11, 835-842, 1980.

10 Nyenje, P. M., Foppen, J. W., Uhlenbrook, S., Kulabako, R., and Muwanga, A.: Eutrophication and nutrient release in urban areas of sub-Saharan Africa - a review, Sci. Total. Environ., 408, 447-455, 2010.

Orchard, E. D., Benitez-Nelson, C. R., Pellechia, P. J., Lomas, M. W., and Dyhrman, S. T.: Polyphosphate in Trichodesmium from the low-phosphorus Sargasso Sea, Limnol. Oceanogr., 55, 2161-2169, 2010.

Pernet-Coudrier, B., Qi, W. X., Liu, H. J., Müller, B., and Berg, M.: Sources and pathways of nutrients in the semi-arid region of Beijing-Tianjin, China, Environ. Sci. Technol., 46, 52945301, 2012.

Ramm, K. and Scheps, V.: Phosphorus balance of a polytrophic shallow lake with consideration of phosphorus release, Hydrobiologia, 342/343, 43-53, 1997.

Reitzel, K., Ahlgren, J., Gogoll, A., and Rydin, E.: Effects of aluminum treatment on phosphorus, carbon, and nitrogen distribution in lake sediment: a ${ }^{31} \mathrm{P}$ NMR study, Water Res., 40, 647654, 2006.

Reitzel, K., Ahlgren, J., Debrabandere, H., Waldebäck, M., Gogoll, A., Tranvik, L., and Rydin, E.: Degradation rates of organic phosphorus in lake sediment, Biogeochemistry, 82, 1528, 2007.

Reitzel, K., Jensen, H. S., Flinedt, M., and Andersen, F.: Identification of dissolved nonreactive phosphorus in freshwater by precipitation with Aluminum and subsequent ${ }^{31} \mathrm{P}$ NMR analysis, Environ. Sci. Technol., 43, 5391-5397, 2009.

so Shinohara, R., Imai, A., Kawasaki, N., Komatsu, K., Kohzu, A., Miura, S., Sano, T., Satou, T., and Tomioka, N.: Biogenic phosphorus compounds in sediment and suspended particles in a shallow eutrophic lake: ${ }^{31} \mathrm{P}$ uuclear magnetic resonance $\left({ }^{31} \mathrm{P} N \mathrm{NR}\right)$ study, Environ. Sci. Technol., 46, 10572-10578, 2012.

\section{Biogenic-P in \\ multi-polluted river \\ sediment \\ W. Q. Zhang et al.}

Title Page

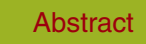

Conclusions

Tables

14

4

Back

Full Screen / Esc

Printer-friendly Version

Interactive Discussion 
Suzumura, M. and Kamatani, A.: Isolation and determination of inositol hexaphosphate in sediments from Tokyo Bay, Geochim. Cosmochim. Ac., 57, 2197-2202, 1993.

Turner, B. L.: Optimizing phosphorus characterization in animal manures by solution phosphorus-31 nuclear magnetic resonance spectroscopy, J. Environ. Qual., 33, 757-766, 52004

Turner, B. L., Mahieu, N., and Condron, L. M.: The phosphorus composition of temperate pasture soils determined by $\mathrm{NaOH}-\mathrm{EDTA}$ extraction and solution ${ }^{31} \mathrm{P}$ NMR spectroscopy, Org. Geochem., 34, 1199-1210, 2003a.

Turner, B. L., Mahieu, N., and Condron, L. M.: Phosphorus-31 nuclear magnetic resonance 10 spectral assignments of phosphorus compounds in soil $\mathrm{NaOH}$-EDTA extracts, Soil Sci. Soc. Am. J., 67, 497-510, 2003b.

Turner, B. L., Cade-Menun, B. J., Condron, L. M., and Newman, S.: Extraction of soil organic phosphorus, Talanta, 66, 294-306, 2005.

Turner, B. L., Newman, S., and Newman, J. M.: Organic phosphorus sequestration in subtropical treatment wetlands, Environ. Sci. Technol., 40, 727-733, 2006.

US EPA: Quality criteria for water-1986, EPA 440/5-86-001, 1986.

Viktorsson, L., Ekeroth, N., Nilsson, M., Kononets, M., and Hall, P. O. J.: Phosphorus recycling in sediments of the central Baltic Sea, Biogeosciences, 10, 3901-3916, doi:10.5194/bg-103901-2013, 2013.

20 Vörösmarty, C. J., Mclntyre, P. B., Gessner, M. O., Dudgeon, D., Prusevich, A., Green, P., Glidden, S., Bunn, S. E., Sullivan, C. A., Liermann, C. R., Davies, P. M.: Global threats to human water security and river biodiversity, Nature, 467, 555-561, 2010.

Wang, J. Y. and Pant, H. K.: Identification of organic phosphorus compounds in the Bronx River bed sediments by phosphorus-31 nuclear magnetic resonance spectroscopy, Environ. Monit. Assess., 171, 309-319, 2010.

Zhang, R. Y., Wu, F. C., He, Z. Q., Zheng, J., Song, B. A., and Jin, L. H.: Phosphorus composition in sediments from seven different trophic lakes, China: a phosphorus-31 NMR study, J. Environ. Qual., 38, 353-359, 2009.
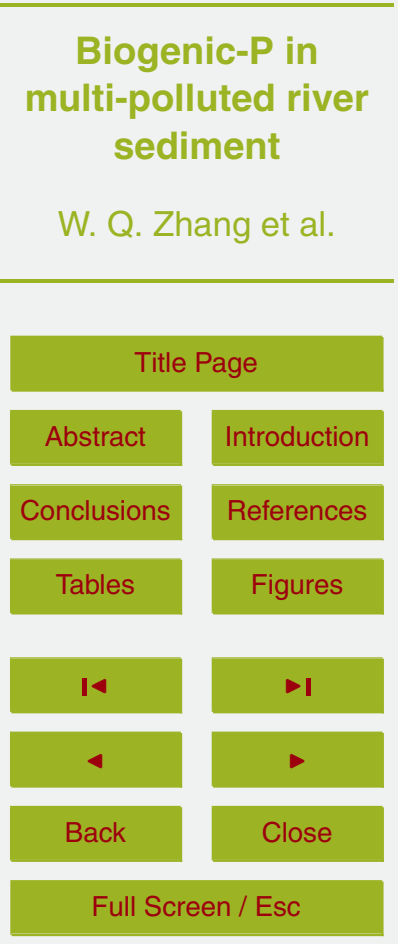

Printer-friendly Version

Interactive Discussion 
Table 1. Physical and chemical properties of sediments in Fuyang River.

\begin{tabular}{|c|c|c|c|c|c|c|c|c|c|c|c|}
\hline \multirow[t]{3}{*}{ River } & \multirow[t]{3}{*}{ Site } & \multirow[t]{3}{*}{ OM (\%) } & \multirow[t]{3}{*}{$\mathrm{C} / \mathrm{P}$} & \multirow[t]{3}{*}{$\mathrm{pH}$} & \multicolumn{7}{|c|}{ Sediment } \\
\hline & & & & & $\mathrm{TP}^{*}$ & Po (\%) & $\mathrm{Al}$ & $\mathrm{Ca}$ & $\mathrm{Fe}$ & $\mathrm{Mg}$ & $\mathrm{Mn}$ \\
\hline & & & & & \multicolumn{2}{|c|}{$\mathrm{mgkg}^{-1 * *}$} & \multicolumn{5}{|c|}{$\mathrm{gkg}^{-1}$} \\
\hline \multirow[t]{7}{*}{ Fuyang River } & 1 & 6.55 & 44.38 & 7.65 & 1186 & $274(23.1)$ & 32.51 & 13.38 & 30.06 & 2.95 & 0.38 \\
\hline & 2 & 8.47 & 21.07 & 7.84 & 3848 & $547(14.2)$ & 5.51 & 25.80 & 42.42 & 5.26 & 0.53 \\
\hline & 3 & 6.44 & 27.10 & 7.35 & 1338 & $210(15.7)$ & 28.43 & 20.97 & 42.50 & 3.13 & 0.63 \\
\hline & 4 & 25.19 & 14.37 & 7.17 & 9829 & $3787(38.5)$ & 17.35 & 14.78 & 44.72 & 4.05 & 0.57 \\
\hline & 5 & 4.87 & 41.04 & 7.54 & 734 & $160(21.8)$ & 18.21 & 15.29 & 36.27 & 3.88 & 0.57 \\
\hline & 6 & 20.81 & 25.62 & 8.27 & 4190 & 2109 (50.3) & 7.18 & 11.17 & 55.54 & 5.53 & 0.52 \\
\hline & 7 & 3.27 & 28.05 & 8.06 & 720 & $88(12.3)$ & 18.81 & 12.95 & 41.02 & 3.89 & 0.65 \\
\hline \multirow[t]{2}{*}{ Niuwei River } & 8 & 4.03 & 32.10 & 7.43 & 733 & $87(11.8)$ & 32.59 & 18.26 & 32.78 & 3.81 & 0.40 \\
\hline & 9 & 11.28 & 35.62 & 6.69 & 2048 & $569(27.8)$ & 22.41 & 13.12 & 45.29 & 5.58 & 0.30 \\
\hline \multirow[t]{2}{*}{ Xiaohe River } & 10 & 5.67 & 26.32 & 7.73 & 1460 & $301(20.6)$ & 35.19 & 18.42 & 34.77 & 4.62 & 0.43 \\
\hline & 11 & 5.43 & 41.24 & 7.48 & 818 & $145(17.7)$ & 34.57 & 14.16 & 45.90 & 4.07 & 0.41 \\
\hline \multirow[t]{4}{*}{ Wangyanggou River } & 12 & 20.69 & 17.24 & 6.95 & 7366 & $3686(50.0)$ & 9.89 & 20.49 & 36.74 & 5.26 & 0.56 \\
\hline & 13 & 2.87 & 33.54 & 8.53 & 574 & $96(16.7)$ & 15.27 & 20.29 & 33.46 & 4.25 & 0.58 \\
\hline & 14 & 2.78 & 33.69 & 7.84 & 462 & $22(4.8)$ & 27.15 & 23.52 & 37.44 & 4.60 & 0.46 \\
\hline & 15 & 9.83 & 19.75 & 7.75 & 3060 & $1570(51.3)$ & 19.60 & 20.89 & 30.88 & 5.18 & 0.45 \\
\hline \multirow[t]{3}{*}{ Shaocunpaigan River } & 16 & 5.69 & 51.40 & 8.02 & 935 & $200(21.3)$ & 20.20 & 12.70 & 34.69 & 3.48 & 0.49 \\
\hline & 17 & 1.99 & 25.88 & 8.52 & 534 & $51(9.6)$ & 27.08 & 21.97 & 32.69 & 4.59 & 0.49 \\
\hline & 18 & 12.09 & 15.78 & 7.25 & 4228 & $2134(50.5)$ & 27.12 & 14.15 & 57.59 & 3.90 & 0.63 \\
\hline
\end{tabular}

* Parentheses indicate the proportion of Po to TP in sediments (\%).

** The concentration is based on the dry weight.
BGD

10, 16269-16294, 2013

Biogenic-P in

multi-polluted river sediment

W. Q. Zhang et al.

\section{Title Page}

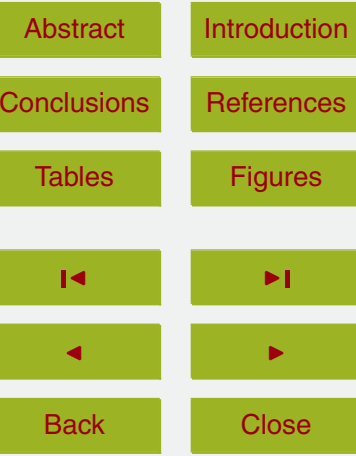

Full Screen / Esc

Printer-friendly Version

Interactive Discussion 
Table 2. Concentrations ${ }^{\mathrm{a}, \mathrm{b}}$ of $\mathrm{P}$ compounds in $\mathrm{NaOH}-\mathrm{EDTA}$ extracts of the sediments determined by solution ${ }^{31} \mathrm{P}-\mathrm{NMR}$.

\begin{tabular}{|c|c|c|c|c|c|c|c|c|c|c|}
\hline \multirow[t]{3}{*}{ River } & \multirow[t]{3}{*}{ Site } & \multirow[t]{2}{*}{ TP } & \multirow[t]{2}{*}{$\mathrm{Po}(\%)$} & \multicolumn{3}{|c|}{ Inorganic $\mathrm{P}$} & \multicolumn{4}{|c|}{ Organic $\mathrm{P}$} \\
\hline & & & & Ortho-P & Pyro-P & Poly-P & Mono-P & Lipid-P & DNA-P & Phon-P \\
\hline & & \multicolumn{9}{|c|}{$\mathrm{mgkg}^{-1}$} \\
\hline \multirow[t]{7}{*}{ Fuyang River } & 1 & 512.7 & $129.1(47.1)^{*}$ & $389.5(75.9)^{* *}$ & $33.7(6.6)$ & $0.2(0.04)$ & $66.7(13.0)$ & $4.2(0.8)$ & $18.4(3.6)$ & n.d. \\
\hline & 2 & 2731.9 & $377.7(69.0)$ & $2340.5(85.7)$ & $20.8(0.8)$ & n.d. & $241.5(8.8)$ & $23.9(0.9)$ & $65.3(2.4)$ & $39.9(1.5)$ \\
\hline & 3 & 857.7 & $113.0(53.7)$ & $746.8(87.1)$ & $6.2(0.7)$ & n.d. & $79.2(9.2)$ & $6.5(0.8)$ & 16.2(1.9) & $2.9(0.3)$ \\
\hline & 4 & 5712.9 & $1657.3(43.8)$ & $4061.6(71.1)$ & $44.2(0.8)$ & n.d. & $1260.6(22.1)$ & $141.1(2.5)$ & $124.2(2.2)$ & $81.3(1.4)$ \\
\hline & 5 & 314.1 & $94.3(58.8)$ & $256.9(81.8)$ & $3.1(0.9)$ & n.d. & $39.8(12.7)$ & $1.8(0.6)$ & 12.4(3.9) & n.d. \\
\hline & 6 & 3299.4 & $1222.5(58.0)$ & $2056.8(62.3)$ & $41.3(1.3)$ & n.d. & $963.4(29.2)$ & $31.2(0.9)$ & $110.9(3.4)$ & $95.7(2.9)$ \\
\hline & 7 & 195.7 & $64.2(72.8)$ & $172.6(88.2)$ & $1.1(0.5)$ & n.d. & $19.9(10.2)$ & n.d. & $2.2(1.1)$ & n.d. \\
\hline \multirow[t]{2}{*}{ Niuwei River } & 8 & 357.5 & $55.5(64.0)$ & $330.2(92.4)$ & $0.8(0.2)$ & n.d. & $23.5(6.6)$ & n.d. & $3.1(0.9)$ & n.d. \\
\hline & 9 & 1607.3 & $388.8(68.3)$ & 1237.2(76.9) & 8.3(0.5.) & n.d. & $325.6(20.3)$ & $6.5(0.4)$ & $22.2(1.4)$ & $7.6(0.5)$ \\
\hline \multirow[t]{2}{*}{ Xiao River } & 10 & 1008.2 & 219.7(73.0) & 786.9(78.1) & $13.7(1.4)$ & n.d. & 181.3(17.9) & $2.9(0.3)$ & 20.1(1.9) & $3.3(0.3)$ \\
\hline & 11 & 487.3 & $52.8(36.5)$ & $427.2(87.7)$ & $1.1(0.2)$ & n.d. & $55.6(11.4)$ & $0.6(0.1)$ & $1.6(0.3)$ & $1.2(0.2)$ \\
\hline \multirow[t]{4}{*}{ Wangyanggou River } & 12 & 4860.1 & $2578.3(70.0)$ & $2194.9(45.2)$ & $41.8(0.9)$ & n.d. & $2220.9(45.7)$ & $133.2(2.7)$ & $121.9(2.5)$ & $147.4(3.0)$ \\
\hline & 13 & 186.4 & $28.8(30.0)$ & 154.4(82.8) & $0.3(0.1)$ & n.d. & $31.1(16.7)$ & n.d. & $0.5(0.3)$ & $0.1(0.1)$ \\
\hline & 14 & 157.6 & $15.4(70.1)$ & $140.8(89.4)$ & $0.3(0.2)$ & n.d. & $13.1(8.3)$ & $0.6(0.4)$ & $1.9(1.3)$ & $0.9(0.6)$ \\
\hline & 15 & 2171.9 & $755.9(48.0)$ & $1394.4(64.2)$ & $36.9(1.7)$ & n.d. & $539.1(24.8)$ & $53.4(2.5)$ & $75.6(3.5)$ & $72.5(3.3)$ \\
\hline \multirow[t]{3}{*}{ Shaocunpaigan River } & 16 & 487.9 & $123.0(61.6)$ & $362.9(74.4)$ & $4.6(0.9)$ & n.d. & $104.6(21.4)$ & $1.9(0.4)$ & $10.9(2.3)$ & $2.8(0.6)$ \\
\hline & 17 & 179.7 & $24.1(47.1)$ & $161.7(90.0)$ & $0.8(0.4)$ & n.d. & $15.1(8.4)$ & n.d. & $2.1(1.2)$ & n.d. \\
\hline & 18 & 3684.5 & $1199.5(56.2)$ & $2527.5(68.6)$ & $32.8(0.9)$ & n.d. & $1009.2(27.4)$ & $14.5(0.4)$ & $92.5(2.5)$ & $8.2(0.2)$ \\
\hline
\end{tabular}

${ }^{a}$ The concentration is based on the dry weight.

${ }^{\mathrm{b}}$ The value was calculated from the concentration in the $\mathrm{NaOH}-\mathrm{EDTA}$ extract and the dry weight.

${ }^{c}$ The proportion of Po in NaOH-EDTA extraction to total Po in sediments (\%).

${ }^{d}$ The proportion of individual $\mathrm{P}$ fraction fraction to total $\mathrm{P}$ in $\mathrm{NaOH}-\mathrm{EDTA}$ extraction.

n.d. not detected.

DNA-P = deoxyribonucleic acids (orthophosphate diesters), Lipid- $\mathrm{P}=$ phospholipid (orthophosphate diesters), Mono- $\mathrm{P}=$ orthophosphate monoesters

Ortho- $\mathrm{P}=$ orthophosphate, $\mathrm{Phon}-\mathrm{P}=$ phosphonate, $\mathrm{Pyro}-\mathrm{P}=$ pyrophosphate, $\mathrm{Ploy}-\mathrm{P}=$ polyphosphate

\section{BGD}

10, 16269-16294, 2013

\section{Biogenic-P in \\ multi-polluted river \\ sediment \\ W. Q. Zhang et al.}

Title Page

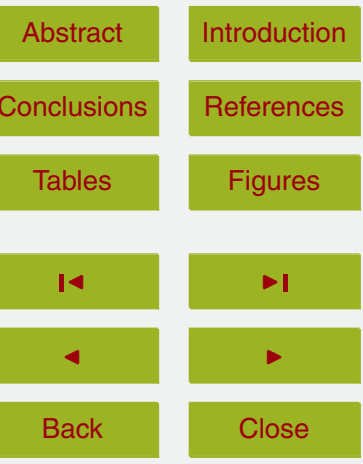

Full Screen / Esc

Printer-friendly Version

Interactive Discussion 
Table 3. Results for Po extraction by ${ }^{31} \mathrm{P}-\mathrm{NMR}$ spectroscopy from other published studies.

\begin{tabular}{|c|c|c|c|c|}
\hline Samples & Extractant & $\begin{array}{l}\text { Extracted Po } \\
\left(\mathrm{mg} \mathrm{kg}^{-1}\right)\end{array}$ & Ortho-P (\%) & Literature \\
\hline $\begin{array}{l}\text { Lake sediments (Seven } \\
\text { different trophic lakes, China) }\end{array}$ & $\mathrm{NaOH}-\mathrm{EDTA}$ & $37-178$ & $36-63$ & Zhang et al. (2009) \\
\hline $\begin{array}{l}\text { Lake sediments (Taihu, } \\
\text { China) }\end{array}$ & $\mathrm{NaOH}-\mathrm{Na}_{2} \mathrm{~S}_{2} \mathrm{O}_{4}$ & $27-101$ & $29-46$ & Bai et al. (2009) \\
\hline $\begin{array}{l}\text { Lake sediment (Lake } \\
\text { Kasumigaura, Japan) }\end{array}$ & $\mathrm{NaOH}-\mathrm{EDTA}$ & $\begin{array}{l}0.92-1.05 \\
\left(\mathrm{mg} \mathrm{g}^{-1}, \mathrm{TP}\right)\end{array}$ & $40-61$ & $\begin{array}{l}\text { Shinohara } \\
\text { et al. (2012) }\end{array}$ \\
\hline Soils (England and Wales) & $\mathrm{NaOH}-\mathrm{EDTA}$ & $257-1083$ & $46-88$ & Turner et al. (2003a) \\
\hline Marine sediments & $\mathrm{NaOH}$ & - & $13-44$ & Ingall et al. (1990) \\
\hline $\begin{array}{l}\text { River sediments (Bronx } \\
\text { River, USA) }\end{array}$ & $\mathrm{NaOH}$ & - & 24-59 (NaOH-P/TP) & Wang and Pant (2010) \\
\hline River sediments & $\mathrm{NaOH}-\mathrm{EDTA}$ & $\begin{array}{l}15.38- \\
2578.34\end{array}$ & $30-73$ & This study \\
\hline
\end{tabular}

\section{Biogenic-P in multi-polluted river sediment}

W. Q. Zhang et al.

Title Page

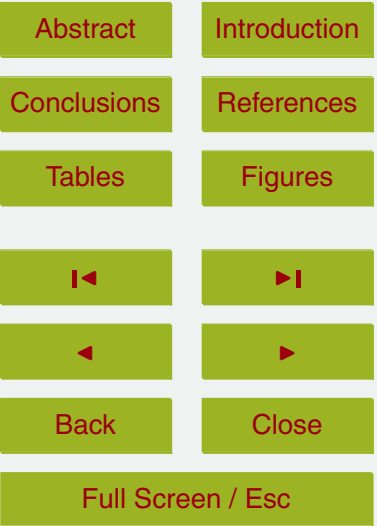

Printer-friendly Version

Interactive Discussion 


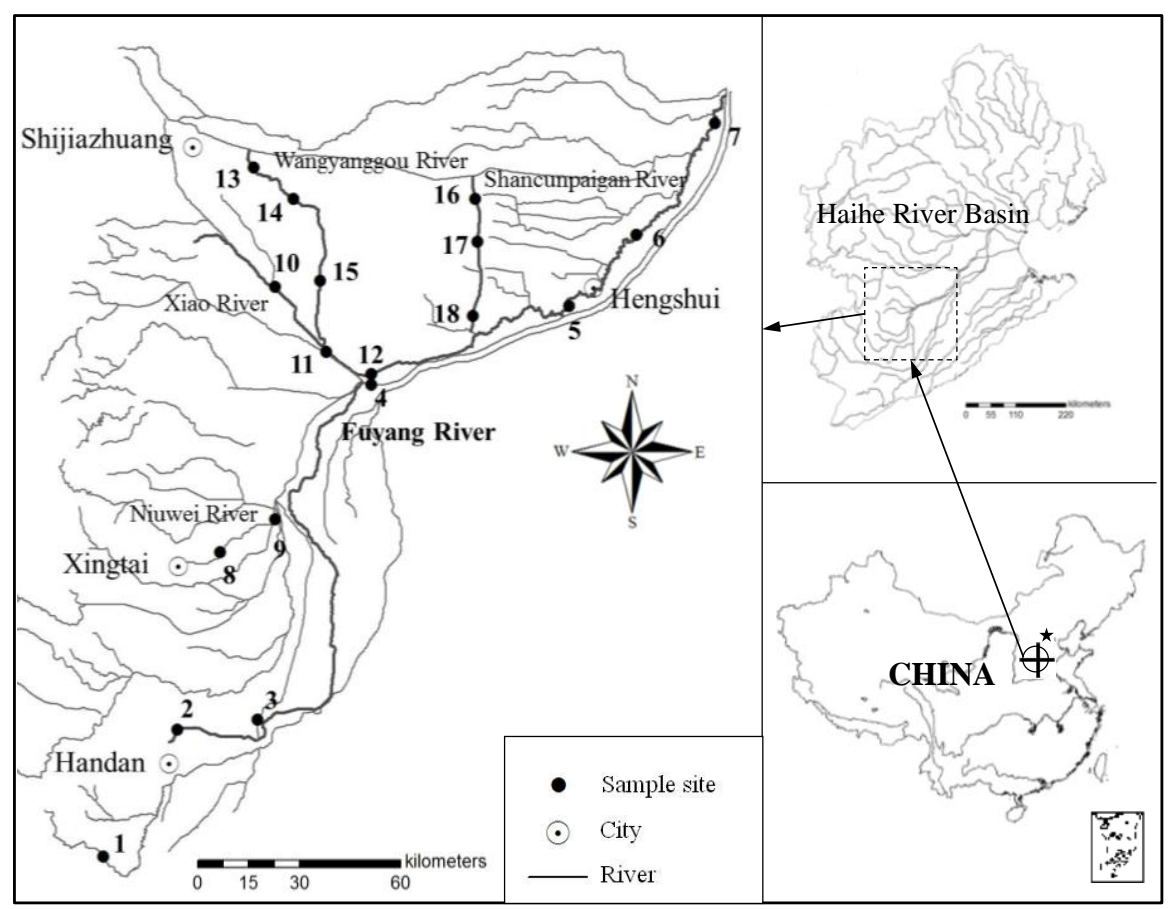

10, 16269-16294, 2013

\section{Biogenic-P in multi-polluted river sediment}

W. Q. Zhang et al.

Title Page

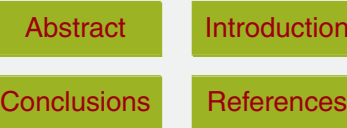

Tables

Figures

14

> I

4

Back

Close

\section{Full Screen / Esc}

Printer-friendly Version

Shaocunpaigan River: 16, 17 and 18.

Interactive Discussion 


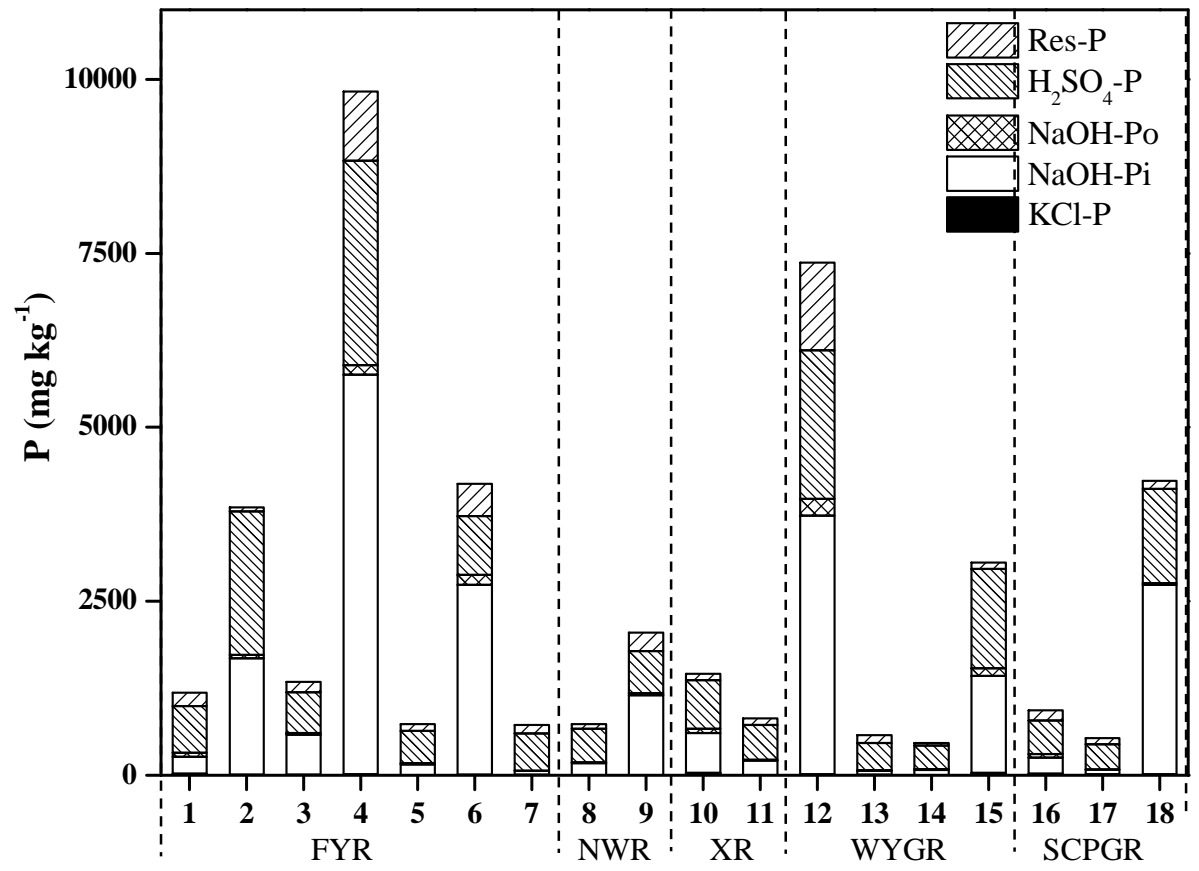

Sample site

Fig. 2. Percentages of $P$ fractionations in the sediments. FYR: Fuyang River; NWR: Niuwei River; XR: Xiao River; WYGR: Wangyanggou River; SCPGR: Shaocunpaigan River.
BGD

$10,16269-16294,2013$

\section{Biogenic-P in \\ multi-polluted river sediment}

W. Q. Zhang et al.

\section{Title Page}

Abstract

Introduction

Conclusions

References

Tables

Figures

14

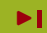

4

Back

Close

\section{Full Screen / Esc}

Printer-friendly Version

Interactive Discussion 


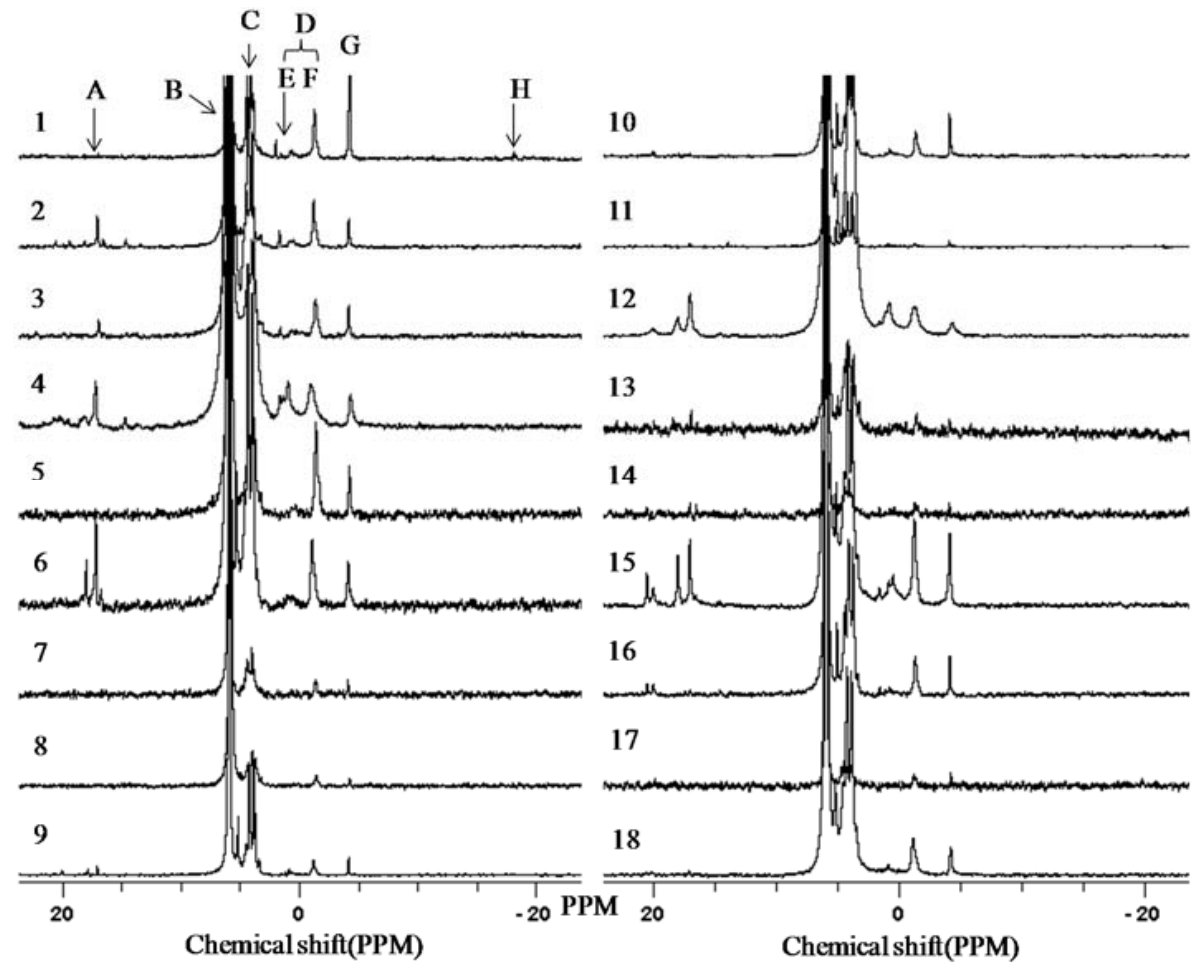

Fig. 3. ${ }^{31} \mathrm{P}-\mathrm{NMR}$ spectra of $\mathrm{NaOH}$-EDTA extracts of the surface sediments in Fuyang River. A: phosphonate; B: orthophosphate; C: orthophosphate monoesters; D: orthophosphate diesters; E: phospholipid; F: deoxyribonucleic acids; G: pyrophosphate; H: polyphosphate. Fuyang River: 1, 2, 3, 4, 5, 6 and 7; Niuwei River: 8 and 9; Xiaohe River: 10 and 11; Wangyanggou River: 12, 13, 14, and 15; Shaocunpaigan River: 16, 17 and 18.
BGD

$10,16269-16294,2013$

\section{Biogenic-P in \\ multi-polluted river sediment}

W. Q. Zhang et al.

\section{Title Page}

Abstract Introduction

Conclusions References

Tables Figures

14 $\rightarrow$

4

Back

Close

\section{Full Screen / Esc}

Printer-friendly Version

Interactive Discussion 

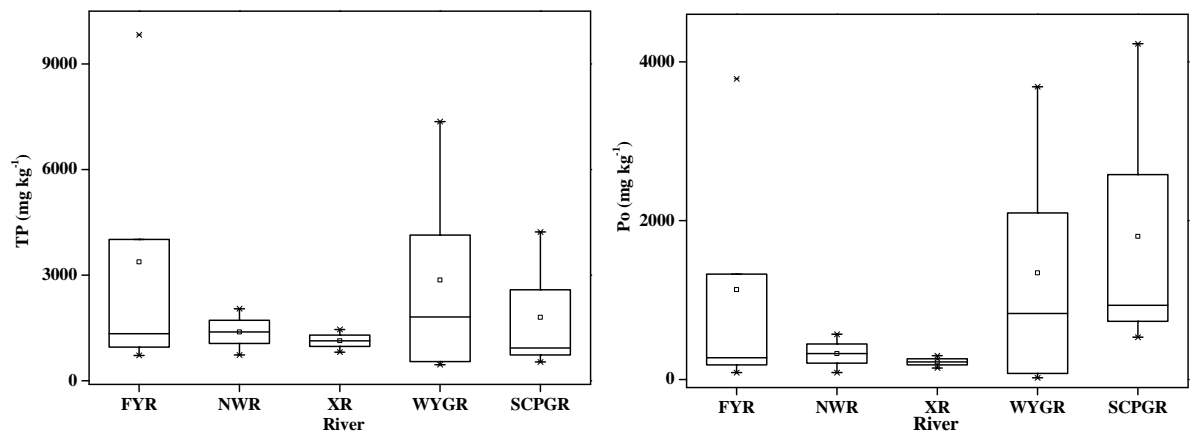

Fig. 4. Concentrations of TP and Po in different river sediments. Box plots show the median (horizontal line), interquartile range (box), and range of the data (whiskers). FYR: Fuyang River; NWR: Niuwei River; XR: Xiao River; WYGR: Wangyanggou River; SCPGR: Shaocunpaigan River.

\section{Biogenic-P in multi-polluted river sediment}

W. Q. Zhang et al.

Title Page

Abstract

Introduction

Conclusions

References

Tables

Figures

14

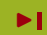

4

Back

Close

Full Screen / Esc

Printer-friendly Version

Interactive Discussion 


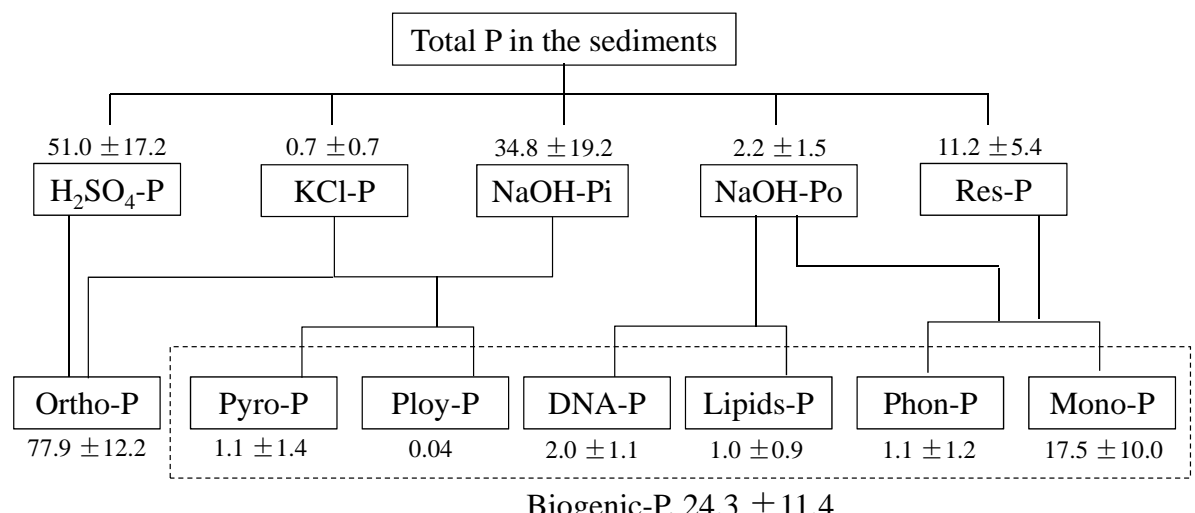

Biogenic-P, $24.3 \pm 11.4$

Fig. 5. Phosphorus compounds in the sediments of Fuyang River (\%). DNA$\mathrm{P}=$ deoxyribonucleic acids (orthophosphate diesters), Lipid- $\mathrm{P}=$ phospholipid (orthophosphate diesters), Mono- $\mathrm{P}=$ orthophosphate monoesters, Ortho- $\mathrm{P}=$ orthophosphate, Phon$\mathrm{P}=$ phosphonate, $\mathrm{Pyro}-\mathrm{P}=$ pyrophosphate, $\mathrm{Ploy}-\mathrm{P}=$ polyphosphate . The values are represent the percentage, and the values are the means and standard deviations of 18 samples.
BGD

$10,16269-16294,2013$

\section{Biogenic-P in \\ multi-polluted river sediment}

W. Q. Zhang et al.

Title Page

Abstract

Introduction

Conclusions

References

Tables

Figures

14

>I

4

Back

Close

\section{Full Screen / Esc}

Printer-friendly Version

Interactive Discussion 